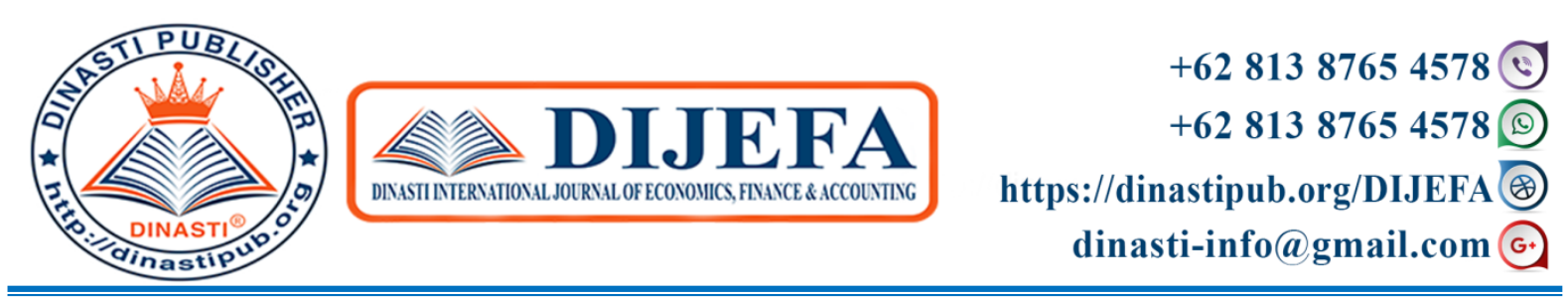

\title{
MODEL OF STUDENT INVESTMENT INTENTION WITH FINANCIAL KNOWLEDGE AS A PREDICTOR THAT MODERATED BY FINANCIAL SELFEFFICACY AND PERCEIVED RISK
}

\author{
Ryan Elfahmi ${ }^{1}$, Ikin Solikin ${ }^{2}$, Nugraha ${ }^{3}$ \\ 1) 2) Universitas Pendidikan Indonesia, West Java, Indonesia
}

\begin{tabular}{|c|c|}
\hline $\begin{array}{l}\text { ARTICLE INFORMATION } \\
\text { Received: 05 April } 2020 \\
\text { Revised: 16 April } 2020 \\
\text { Issued: } 27 \text { April } 2020 \\
\text { Corresponding author: } \\
\text { Ryan Elfahmi } \\
\text { E-mail: } \\
\text { ryanelfahmi@upi.edu } \\
\text { dosen01363@unpam.ac.id }\end{array}$ & $\begin{array}{l}\text { Abstract: This study aims to predict students' } \\
\text { investment intentions in the Indonesia Stock Exchange. } \\
\text { The questions in this study are whether financial } \\
\text { knowledge shows a significant effect on student } \\
\text { investment intentions on the Indonesia Stock } \\
\text { Exchange, whether financial self-eficacy shows a } \\
\text { significant effect in strengthening or weakening } \\
\text { student investment intentions on the Indonesia Stock } \\
\text { Exchange and whether the perceived risk shows a } \\
\text { significant effect in strengthening or weakening } \\
\text { student investment intentions in the Indonesia Stock } \\
\text { Exchange. The analysis technique in this study using } \\
\text { SPSS ver.21 and analyzed by regression PROCESS } \\
\text { v3.4 by Andrew F. Hayes. The sampling method is } \\
\text { purposive sampling, with several criteria developed } \\
\text { previously. Questionnaires are used to collect data } \\
\text { from respondents. Respondents in this study were } \\
\text { students at the University of Pamulang, South } \\
\text { Tangerang. A total of } 400 \text { respondents participated. } \\
\text { Based on the analysis, Financial Knowledge influences } \\
\text { students' investment intentions on the Indonesia Stock } \\
\text { Exchange. Financial self-efficacy does not shows a } \\
\text { significant influence in strengthening student } \\
\text { investment intentions on the Indonesia Stock } \\
\text { Exchange. The perceived risk shows a significant effect } \\
\text { in weakening students' investment intentions on the } \\
\text { Indonesia Stock Exchange. } \\
\text { Keywords: Investment Intentions, Financial Knowledge, } \\
\text { Financial Self-efficacy, Perceived Risk. }\end{array}$ \\
\hline
\end{tabular}

\section{INTRODUCTION}

The capital market in Indonesia has a long history that was even present before Indonesia's independence. The existing Indonesia Stock Exchange (IDX) actually started 
operating since December 1, 2007 which is a combination of the Jakarta Stock Exchange as a stock market with the Surabaya Stock Exchange as a bond and derivative market.

The Indonesia Stock Exchange has a very interesting development in terms of investor participation. Until the end of 2017, investor participation in the Indonesia Stock Exchange is still dominated by foreign investors. This causes the flow of foreign funds in and out of Indonesia due to the activity of foreign investors on the Indonesia Stock Exchange. This situation has influenced macroeconomic conditions in Indonesia at least in terms of the stability of the value of the rupiah compared to foreign currencies, especially the US Dollar, which is still the dominant currency used in international trade. Further developments began to improve in 2018 as local investors slowly began to take over the dominance of participation in the Indonesia Stock Exchange. At the beginning of 2019, local investors had become the majority in participating in the Indonesia Stock Exchange.

The next interesting development is the participation of millennial generation in the capital market. However, the participation of millennials in the Indonesia Stock Exchange mostly does not trade alone but in mutual fund products, which means that their funds are managed by investment managers from securities companies. It is suspected that knowledge about stock market trading is their reason for not being directly involved in making decisions in trading, if this is proven to be true then it is a positive awareness because based on research, individual trading tends to damage their financial wealth (Coval, Hirshleifer, Shumway, 2005 ). Barber, Dean, and Zhu (2008) even explained that the trading activities of individual investors are not reasonable enough and do not achieve impressive returns. The trade that is most detrimental to individual investors is the trade that is the most aggressive they do.

The behavior of individual investors, especially millennial generation in their trading activities in the stock market, is always interesting to observe and investigate further. Although most of the millennial generation individual investors participate in mutual fund products offered by securities companies, the number of millennial generation individual investors who participate and are actively involved in trading on the Indonesia Stock Exchange also continues to grow. This is inseparable from the role of the government and securities companies in aggressively educating prospective new investors to invest in the Indonesia Stock Exchange. The participation of millennial generation individual investors in the process have succeeded in scoring good performance and some have not yet succeeded or underperformed. Some underperforming individual investors have withdrawn their participation, but some have survived but turned to mutual fund products and some have persisted and continued to learn to improve their ability to invest in trading on the Indonesia Stock Exchange. $\mathrm{t}$ is important to read the behavior of individual investors, especially millennial generation, because even if they are individuals, the similarity of their behavior will have a group effect that can affect the price movement of a stock on the capital market. Nofsinger and Sias (1999) explained that there is a positive correlation between changes in institutional ownership and contemporary relations. It was also further stated that trading activities by one group of investors could certainly have an effect on stock prices. 
When viewed from the development of the theory of finance has long been based on classical financial theory which is basically focused on objective information in the micro scope and macro environmental situation. These classical theories assume that all investors are rational when in fact it is often found that normal investors especially individual investors want things that are not rational.

Classical theory also views market conditions as an efficient market which in reality the market has a very high complexity.

Assumptions and points of view of classical financial theories encourage investors in general to use the Mean-Variance Portfolio Theory and the Capital Asset Pricing Model in structuring portfolios and valuing their assets. Though it is often found that investors take a more subjective approach in forming a portfolio or valuing assets so that behavior-based decision making becomes a choice or often a behavior-based approach is carried out to complement a decision-making model that is also composed of components of classical financial theory.

Behavior-based finance began to develop trying to balance out classical financial theories that had lasted for a very long time. The disciplines of psychology and sociology became the dominant drivers in the development of behavior-based finance. The involvement of the three disciplines is explained by Ricciardi (Ricciardi \& Simon, 2000). Fama (1970) explains that the market is efficient because the prices of securities that are formed at a certain time reflect all the information available at the time, this is contrary to the opinion of Sewell (2007) which states that the market is inefficient because the behavior of financial practitioners is influenced by psychological factors which further impact the market.

Furthermore, investor behavior in the real world compared to theories about investor behavior will shape behavior-based finance (Jordan, 2015).

Investment intention as a predictor for behavior in this case is the behavior to invest becomes important considering that investment in an entrepreneurial framework provides an important role in increasing a country's economic growth (Castaño et al., 2016). Millennial generation individual investors have different backgrounds, some are financially knowledgeable and some are not. From these different background knowledge each of the individual investors has different performance in trading their shares. In terms of ownership of financial knowledge, it is interesting to study further whether financial knowledge is strong enough as a predictor in reading the behavior of millennial generation individual investors in making decisions on the stock market, or even earlier whether financial knowledge held by individuals can arouse their intention to participate in investments on the stock market.

Investment intentions among potential investors are measured by financial knowledge and personality traits that have been incorporated into the basic construction of Theory Plan Behavior. Financial knowledge is considered, because it plays an important role in determining financial behavior (Khan, 2016; Tauni et al., 2017).

In previous studies, good financial behavior is often associated with a higher level of financial knowledge (Edmiston and Gillett-Fisher, 2006). But there is literature that explains 
the relationship between financial knowledge and taking risks when investing (Wang, 2009). On the other hand, people who have better financial knowledge in terms of financial management (Lusardi and Mitchell, 2014). These people are more likely to diversify risk by spreading their funds across a variety of different financial assets (Abreu and Mendes, 2010). Financial knowledge might also lead someone to deepen their financial skills and attitudes (Hassan Al-Tamimi and Anood Bin Kalli, 2009).

Accuracy in decision making depends on objective knowledge, while confidence when making decisions is influenced by subjective knowledge (Wang, 2009). This is an important reason why financial knowledge can be a predictor of investment intentions of potential individual investors.

Objective financial knowledge also helps in processing financial knowledge and empowers individuals analytically when making decisions (Bettman and Sujan, 1987), whereas individuals with lower levels of objective financial knowledge cannot produce or decipher thoughts. This leads to an assumption that when objective financial knowledge is at a low level, decisions will be difficult for individuals to make, so it is very logical that individuals will try to collect as much information as possible in relation to the object being observed in order to have knowledge who is strong enough to make decisions. It has been observed that financial ignorance can have catastrophic results such as: ending up with higher debt and higher loan interest rates (Lusardi and de Bassa Scheresberg, 2013; Lusardi and Tufano, 2015), borrowing more and saving less (Stango and Zinman, 2009).

Financial self-efficacy can encourage individuals to be more courageous in taking risks, this is evidenced in previous studies that confidence (eg financial confidence) is a strong predictor of investment risk taking (Forbes and Kara, 2010; Chatterjee et al., 2011). Financial self-efficacy can affect one's financial knowledge which can further influence risk taking, in line with the results of Krueger and Dickson (1994) which shows that trust influences risk taking by influencing one's insight about opportunities and threats. Research on financial self-efficacy has even touched the realm of gender, Badunenko et al. (2009) and Montford and Goldsmith (2016) found that women have lower levels of financial confidence than men, so they choose to invest with low risk, which paradoxically results in lower returns in the long run. These studies imply that financial self-efficacy helps in exploring investment opportunities and leads to the determination of more specific strategies in capturing new investors.

The results of Akhtar and Das's research (2019) in India show that financial selfefficacy are positively and significantly related to investment intentions. With different backgrounds between India and Indonesia and different stock markets, this study will later prove whether financial self-efficacy also have the same effect on potential individual investors in the Indonesian stock market as in the Indian stock market. Perceived risk" has begun to be studied in areas such as online consumer products and services, e-banking, and the stock market. However, the focus on measuring risk is still diverse. Consumer goods focus on product risk, performance risk or financial risk (Forsythe and Shi, 2003), focusing on the internet banking industry focusing on social risk, time lost 
risk, opportunity cost risk, and information risk (Kassim \& Ramayah, 2015). The involvement of psychology in investment intentions is also emphasized by Baker and Nofsinger (2010) who state that we are all human beings, so our behavior is certainly influenced by psychology.

People seem to have a tendency to prevent risk compared to maximizing utility when making investment decisions, this which drives "perceived risk" to be a very important instrument in predicting investor behavior (Mitchell, 1999).

In several studies in finance, risk perception is measured by attitudes towards risk such as risk taking and risk avoidance (Kahneman and Tversky, 1979; Barberis and Huang, 2001; Mayfield et al., 2008).

The formulation of the problem in this study is financial knowledge as a predictor mediated by attitudes and subjective norms and moderating variables of financial beliefs and risks that can be used to predict investments in millennials on the Indonesia Stock Exchange. The objectives of this study are:

1. To find out whether financial financial knowledge shows a significant effect on student investment intentions on the Indonesia Stock Exchange.

2. To find out whether financial self-eficacy shows a significant effect in strengthening or weakening student investment intentions on the Indonesia Stock Exchange

3. To find out whether the perceived risk shows a significant effect in strengthening or weakening student investment intentions in the Indonesia Stock Exchange.

\section{LITERATURE REVIEW}

Entrepreneurial intentions have been identified as a person's first action before conducting business or the production and initial sale of a business (Najafabadi et al., 2016). Referring to the above definition, investment intentions can be defined as a person's first action before investing in a capital market.

Financial knowledge can be interpreted as information obtained through learning, organizing, representing and storing it in memory (Wang, 2009).

Research has suggested that financial knowledge consists of two basic components, namely objective financial knowledge and subjective financial knowledge (Wang, 2009). Objective financial knowledge facilitates knowledge acquisition, whereas subjective financial knowledge increases the level of reliability of existing knowledge (Alba and Hutchinson, 2000).

So, it can be said that objective knowledge refers to actual knowledge while subjective knowledge includes one's level of trust in existing knowledge (Brucks, 1985). Knowledgeable individuals are able to categorize financial information in various classes of financial assets rather than processing it through different attributes (Chang, 2004). These individuals are able to decipher their knowledge, skills and interpret financial information (Wang, 2006).

According to Klapper et al. (2015), individuals with knowledge of four basic financial concepts, namely, counting, risk diversification, inflation and compound interest, can only be said to be financially literate. 
Self-efficacy is one's personal belief in one's own ability to achieve goals (Top, Colakoglu, \& Dilek, 2012). Bandura (1977) defines self-efficacy as someone's beliefs about their ability to organize and carry out actions to achieve a goal. Referring to these definitions, financial self-efficacy can be interpreted as an individual's personal confidence in his own financial ability to achieve goals. Self-efficacy trust structures were first applied by Bandura (1982) to explain human behavior as belief in individual abilities and are defined to regulate and implement operational units to achieve certain goals. One important structure in decision making based on intention is entrepreneurial self-efficacy. Chen, Greene, and Crick (1998) define this as an assessment of the capacities and abilities of individuals who are prepared for work for which they feel their abilities are better. Self-efficacy includes confidence in individual competencies to complete tasks efficiently and the belief that successful campaigns produce predetermined conclusions (Rahmanian Kushki et al., 2011). Entrepreneurial self-efficacy is an explanatory variable that determines the strength of entrepreneurial intentions and the probability of intention to carry out entrepreneurial activities, which distinguish entrepreneurs from others (Boyd \& Vozikis, 1994).

Bauer (1960), initially stated that perceived risk was only involved in subjective risk. Perceived risk is defined that any consumer action will produce unanticipated consequences with anything that comes close to certainty, and some of which at least tends to be unpleasant "(Bauer, 1960). Perceived risk is also seen as" the subjective hope of citizens to suffer loss in pursuing the outcome of desire "(Warkentin et al., 2002. p. 160).

The conceptual model proposed in this study :

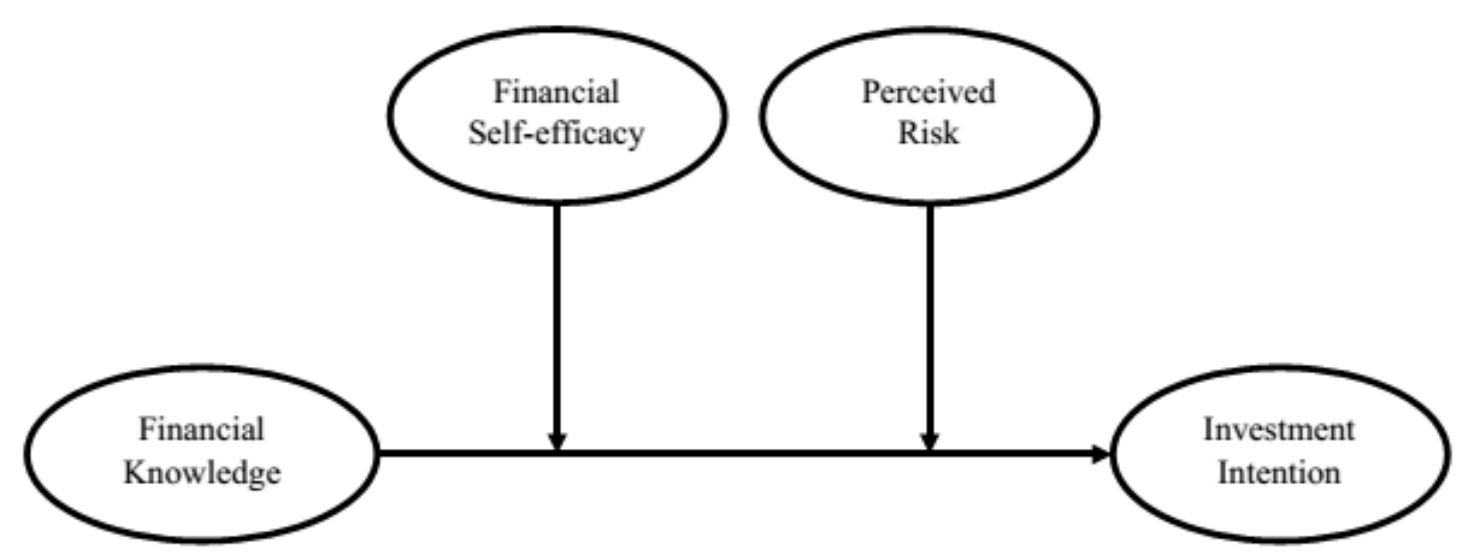

Picture 1. Conceptual Model

The hypotheses in this study are:

H1: Financial knowledge shows a significant effect on student investment intentions on the Indonesia Stock Exchange.

H2: Financial self-eficacy shows a significant effect in strengthening student investment intentions on the Indonesia Stock Exchange.

H3: Phe perceived risk shows a significant effect in weakening student investment intentions in the Indonesia Stock Exchange. 


\section{RESEARCH METHODS}

This research is based on responses from potential individual investors. So the questionnaire was created to collect all responses from potential individual investors. The questionnaire format will be tested by several financial professionals.

Financial knowledge is measured through statements based on the basic concepts needed when making financial decisions. Respondents were asked to rate their responses on a five-point scale.

The perceived behavioral control of investments is replaced with Financial Selfefficacy (FSE) and perceived risk. Six statements were adapted from the FSE scale (Lown, 2011) and respondents were asked to rate their responses on a five-point scale.

Investment intentions are measured using three statements adapted from Chen (2007). Participants are asked to rate their approval or disapproval with the intention to invest in the stock market regularly and to encourage friends and family to invest in the stock market. They were also asked to respond if they intend to invest in the stock market in the future.

Data for this study came from self-administered questionnaires filled out by respondents from universities in South Tangerang. The sample size was taken by considering the population and calculated at a 95\% confidence level. Respondents are drawn from individuals who have earned income and have received education related to finance and capital markets or respondents who have sought financial advice from financial service providers in Banten or individuals who have participated in courses related to financial training.

This study uses a quantitative and cross-sectional approach in which a questionnairebased survey is conducted to collect responses from potential individual investors as respondents. AMOS and SPSS will be used in data processing and analysis in this study to build a hypothetical relationship between constructs.

\section{FINDINGS AND DISCUSSION}

After the reliability and validity requirements are met, the data is tested for the proposed conceptual model (Figure 1). In the proposed conceptual model, the results of the study show that the structural model is quite fit and has very good explanatory power (R-sq = 0.799 , ie 79.9 percent) in measuring the investment intentions of potential individual investors (Table I).

Table 1. Model Summary

\begin{tabular}{rrrrrrr}
\hline R & R-sq & MSE & F & df1 & df2 & p \\
\hline 0,8941 & 0,7994 & 1,4084 & 313,9956 & 5,0000 & 394,0000 & 0,0000 \\
\hline
\end{tabular}

The findings show (Table 2) that the construction of Financial Knowledge is positively and significantly related to investment intentions $(\beta=0.7549, p<0.001)$, thus providing support to H1. So, this study illustrates the usefulness of Financial Knowledge in predicting the investment intentions of prospective South Tangerang student investors in the Indonesian Stock Market. Thus, proving support for previous studies, e.g. Grable (2000), Wang (2009), Almenberg and Dreber (2015) and Akhtar and Das (2019), who have shown 
that financial knowledge directly influences the intention to participate in the stock market among individuals.

Table 2. summary of hypothesis test results

\begin{tabular}{lrrrr}
\hline & Coeff & Se & t & $\mathrm{p}$ \\
\hline Constant & $-1,0792$ & 3,2558 & $-0,3315$ & 0,7405 \\
\hline FK & 0,7549 & 0,2229 & 3,3864 & 0,0008 \\
\hline FSE & 0,2825 & 0,0964 & 2,9299 & 0,0036 \\
\hline FK*FSE & $-0,0103$ & 0,0066 & $-1,5584$ & 0,1199 \\
\hline PR & 0,1688 & 0,2005 & 0,8421 & 0,4002 \\
\hline FK*PR & $-0,0349$ & 0,0141 & $-2,4675$ & 0,0140 \\
\hline
\end{tabular}

To test the proposed $\mathrm{H} 2$ moderation from the structural diagram constructed (Figure 2). Financial Self-efficacy (FSE) was calculated using SPSS ver.21 and analyzed by regression PROCESS v3.4 by Andrew F. Hayes using model 2. The findings from the moderation model (table 2 ) show that the standard effect of the term FK*FSE interaction $(\beta=$ $-0,0103, p>0.05)$ with investment intentions indicated that the financial self-efficacy does not moderate the relationship between Financial Knowledge and investment intentions. Therefore, $\mathrm{H} 2$ is rejected. However, there are interesting findings (table 2) that although financial self-efficacy does not moderate the relationship between financial knowledge and investment intentions, financial self-efficacy positively affects investment intentions directly as an independent variable $(\beta=0,2825, \mathrm{p}<0.05)$. This finding supports the results of Phan and Zhou's (2014) study which explains that financial self-efficacy as one of the basic constructs of TBP has a significant relationship with investment intentions. This study also still supports Bandura's study $(1977,1986)$, which states that financial self-efficacy plays a major role in outlining individual financial behavior, even under uncertainty situations (Amatucci and Crawley, 2011; Lown, 2011).

To test the proposed H3 moderation from the structural diagram constructed (Figure 2). Perceived risk (PR) was calculated using SPSS ver.21 and analyzed by regression PROCESS v3.4 by Andrew F. Hayes using model 2. Findings from the moderation model (table 2 ) show that the standard effect of the interaction term FK*PR $(\beta=-0.0349, p<0.05)$ with investment intentions indicating that perceived risk negatively moderates the relationship between Financial Knowledge and investment intentions. Therefore, H3 is supported. It appears that the relationship between financial knowledge and investment intentions is partly moderated by perceived risk. This finding supports Wang's previous study (2009), which has illustrated the role of financial knowledge in future orientation, risk taking and investment decisions. Another interesting finding in this study is that the perceived risk is purely negatively moderating the effect of financial knowledge on investment intentions (table 2). In this study the perceived risk does not affect investment intentions directly as an independent variable $(\beta=0.1688, \mathrm{p}>0.05)$. 


\section{CONCLUSION AND SUGESTION}

The conclusions that can be drawn from this study are:

1. Financial knowledge shows a significant effect on student investment intentions on the Indonesia Stock Exchange.

2. Financial self-eficacy does not shows a significant effect in strengthening student investment intentions on the Indonesia Stock Exchange.

3. The perceived risk shows a significant effect in weakening student investment intentions on the Indonesia Stock Exchange.

It is recommended to expand this research by using constructs that can strengthen the investment intention model or further towards testing the investment behavioral model.

\section{REFERENCE}

Abreu, M., \& Mendes, V. (2010). Financial literacy and portfolio diversification. Quantitative finance, 10(5), 515-528.

Akhtar, F., \& Das, N. (2019). Predictors of investment intention in Indian stock markets: Extending the theory of planned behaviour. International Journal of Bank Marketing, 37(1), 97-119.

Alba, J. W., \& Hutchinson, J. W. (2000). Knowledge calibration: What consumers know and what they think they know. Journal of consumer research, 27(2), 123-156.

Almenberg, J., \& Dreber, A. (2015). Gender, stock market participation and financial literacy. Economics Letters, 137, 140-142.

Al-Tamimi, H. A. H. (2009). Financial literacy and investment decisions of UAE investors. The Journal of Risk Finance.

Amatucci, F. M., \& Crawley, D. C. (2011). Financial self-efficacy among women entrepreneurs. International Journal of Gender and Entrepreneurship.

Badunenko, O., Barasinska, N., \& Schäfer, D. (2009). Are private equity investors good or evil?.

Baker, H. K., \& Nofsinger, J. R. (Eds.). (2010). Behavioral finance: investors, corporations, and markets (Vol. 6). John Wiley \& Sons.

Bandura, A. (1977). Self-efficacy: toward a unifying theory of behavioral change. Psychological review, 84(2), 191.

Bandura, A. (1982). Self-efficacy mechanism in human agency. American psychologist, 37(2), 122.

Barber, B. M., Odean, T., \& Zhu, N. (2008). Do retail trades move markets?. The Review of Financial Studies, 22(1), 151-186.

Barberis, N., \& Huang, M. (2001). Mental accounting, loss aversion, and individual stock returns. the Journal of Finance, 56(4), 1247-1292.

Bauer, R. A. (1960). Consumer behavior as risk taking. Chicago, IL, 384-398.

Bettman, J. R., \& Sujan, M. (1987). Effects of framing on evaluation of comparable and noncomparable alternatives by expert and novice consumers. Journal of Consumer Research, 14(2), 141-154. 
Boyd, N. G., \& Vozikis, G. S. (1994). The influence of self-efficacy on the development of entrepreneurial intentions and actions. Entrepreneurship theory and practice, 18(4), 63-77.

Brucks, M. (1985). The effects of product class knowledge on information search behavior. Journal of consumer research, 12(1), 1-16.

Chang, C. (2004). The interplay of product class knowledge and trial experience in attitude formation. Journal of Advertising, 33(1), 83-92.

Chatterjee, S., Finke, M., \& Harness, N. (2011). The impact of self-efficacy on wealth accumulation and portfolio choice. Applied Economics Letters, 18(7), 627-631.

Chen, C. C., Greene, P. G., \& Crick, A. (1998). Does entrepreneurial self-efficacy distinguish entrepreneurs from managers?. Journal of business venturing, 13(4), 295-316.

Chen, M. F. (2007). Consumer attitudes and purchase intentions in relation to organic foods in Taiwan: Moderating effects of food-related personality traits. Food Quality and preference, 18(7), 1008-1021.

Coval, J. D., Hirshleifer, D. A., \& Shumway, T. (2005). Can individual investors beat the market?.

Edmiston, K. D., \& Gillett-Fisher, M. C. (2006). Financial education at the workplace. Community Affairs, Working Paper 06-02.[Online] Available: http://www. kc. frb. org/publicat/cap/gillettfisher_edmiston_financial_education_april_2006._pdf (February 1, 2011).

Forbes, J., \& Kara, S. M. (2010). Confidence mediates how investment knowledge influences investing self-efficacy. Journal of economic psychology, 31(3), 435-443.

Forsythe, S. M., \& Shi, B. (2003). Consumer patronage and risk perceptions in Internet shopping. Journal of Business research, 56(11), 867-875.

Grable, J. E. (2000). Financial risk tolerance and additional factors that affect risk taking in everyday money matters. Journal of business and psychology, 14(4), 625-630.

Hayes, A. F. (2017). Introduction to mediation, moderation, and conditional process analysis: A regression-based approach. Guilford publications.

Kassim, N. M., \& Ramayah, T. (2015). Perceived risk factors influence on intention to continue using Internet banking among Malaysians. Global Business Review, 16(3), 393-414.

Khan, S. (2016). Impact of financial literacy, financial knowledge, moderating role of risk perception on investment decision. Financial Knowledge, Moderating Role of Risk Perception on Investment Decision (February 4, 2016).

Klapper, L., Lusardi, A., \& Van Oudheusden, P. (2015). Financial literacy around the world. World Bank. Washington DC: World Bank.

Krueger Jr, N., \& Dickson, P. R. (1994). How believing in ourselves increases risk taking: Perceived self-efficacy and opportunity recognition. Decision Sciences, 25(3), 385400.

Lown, J. M. (2011). Development and validation of a financial self-efficacy scale. Journal of Financial Counseling and Planning, 22(2), 54. 
Lusardi, A., \& Mitchell, O. S. (2014). The economic importance of financial literacy: Theory and evidence. Journal of economic literature, 52(1), 5-44.

Lusardi, A., \& Scheresberg, C. D. B. (2013). Financial literacy and high-cost borrowing in the United States (No. w18969). National Bureau of Economic Research.

Lusardi, A., \& Tufano, P. (2015). Debt literacy, financial experiences, and overindebtedness. Journal of Pension Economics \& Finance, 14(4), 332-368.

Malkiel, B. G., \& Fama, E. F. (1970). Efficient capital markets: A review of theory and empirical work. The journal of Finance, 25(2), 383-417.

Mayfield, C., Perdue, G., \& Wooten, K. (2008). Investment management and personality type. Financial services review, 17(3), 219-236.

Mitchell, V. (1992). Understanding Consumers' Behaviour: Can Perceived Risk Theory Help? Management Decision, 30(3). doi:10.1108/00251749210013050

Montford, W., \& Goldsmith, R. E. (2016). How gender and financial self-efficacy influence investment risk taking. International Journal of Consumer Studies, 40(1), 101-106.

Nofsinger, J. R., \& Sias, R. W. (1999). Herding and feedback trading by institutional and individual investors. The Journal of finance, 54(6), 2263-2295.

Omidi Najafabadi, M., Zamani, M., \& Mirdamadi, M. (2016). Designing a model for entrepreneurial intentions of agricultural students. Journal Of Education For Business, 91(6), 338-346.

Pennebaker, J. W., Boyd, R. L., Jordan, K., \& Blackburn, K. (2015). The development and psychometric properties of LIWC2015.

Ricciardi, V., \& Simon, H. K. (2000). What is behavioral finance?. Business, Education \& Technology Journal, 2(2), 1-9.

Sewell, M. (2007). Behavioural finance. University of Cambridge, 1-14.

Stango, V., \& Zinman, J. (2009). Exponential growth bias and household finance. The Journal of Finance, 64(6), 2807-2849.

Top, S., Çolakoğlu, N., \& Dilek, S. (2012). Evaluating entrepreneurship intentions of vocational high school pupils based on self-efficacy concept. Procedia-Social and Behavioral Sciences, 58, 934-943.

Tversky, A., \& Kahneman, D. (1979). Prospect theory: An analysis of decision under risk. Econometrica, 47(2), 263-291.

Wang, A. (2009). Interplay of investors' financial knowledge and risk taking. The journal of behavioral finance, 10(4), 204-213.

Wang, S. L. A. (2006). The effects of audience knowledge on message processing of editorial content. Journal of Marketing Communications, 12(4), 281-296.

Warkentin, M., Gefen, D., Pavlou, P. A., \& Rose, G. M. (2002). Encouraging citizen adoption of e-government by building trust. Electronic markets, 12(3), 157-162. 